\title{
KATECHEZA I LITURGIA: W KIERUNKU ODNOWY
}

Katecheza nie jest wprost liturgia, a liturgia nie jest katechezą w pełnym tego słowa znaczeniu. Nie można jednak tych dwóch rzeczywistości oddzielić, ponieważ istnieje silny związek między katechezą i liturgią. Liturgia jest wypełnieniem katechezy, a katecheza potrzebuje liturgii. I chociaż katecheza jest w służbie liturgii, a liturgia jest wypełnieniem dla katechezy, to ich wzajemna relacja jest nierozerwalna.

Związkiem katechezy z liturgią zajmuje się katechetyka materialna, która po Piśmie Świętym właśnie liturgię czyni jednym z głównych źródeł dla katechezy $^{1}$. Warto zauważyć, że powstało już szereg poważnych opracowań w tym zakresie ${ }^{2}$, ale ciągle istnieje konieczność prezentacji tego zagadnienia w kontekście świata, który zmierza do sekularyzacji i laicyzacji, a także do dechrystianizacji współczesnego odbiorcy katechezy w sytuacji szerzących się sekt i mody na tzw. religie Dalekiego Wschodu. Ponadto świat współczesny

* Ks. Marek Kowalczyk, dr katechetyki, adiunkt na WT UAM w Poznaniu (sekcja w Gnieźnie); wykładowca katechetyki i pedagogiki w Prymasowskim Wyższym Seminarium Duchownym w Gnieźnie.

${ }^{1}$ Zob. A. Hajduk, Wychowanie liturgiczne w katechezie, w: Katechetyka materialna, red. J. Stala, Tarnów 2002, s. 93-133.

${ }^{2}$ Należy tu wymienić m.in.: A. Hajduk, Katecheza i liturgia, Kraków 1999; S. Kulpaczyński (red.), Celebracje w katechezie, Kraków 1999; J. Charytański, Liturgia w katechezie, w: W kręgu zadań i treści katechezy, Warszawa 1992, s. 81-88. 
jest bardzo stechnicyzowany, co sprawia, że odbiorca katechezy nie rozumie wielu znaków i symboli liturgicznych, za pomocą których mógłby wejść w relację z Bogiem. Powstaje więc ogromna potrzeba uwrażliwienia współczesnego człowieka na swoisty ,język" znaków i symboli oraz umiejętności posługiwania się nimi w świadomym wyrażaniu swojej wiary. W jaki sposób przywrócić czytelność znaków wykonywanych w czasie liturgii? Czy dobrze przygotowana liturgia może stać się przyczynkiem do wejścia na drogę wiary? Jak spotkać Boga w liturgii? Czy umiejętnie prowadzona katecheza prowadzi do oddania czci Bogu przez liturgię? Na potrzebę refleksji na ten temat wskazuje także fakt, że nie wszyscy uczestnicy katechezy w szkole uczęszczają na niedzielną Eucharystię ${ }^{3}$. Są tacy, którzy wcale nie chodzą do Kościoła lub chodzą nieregularnie. Co w tej sytuacji może i powinien (z)robić katecheta, aby niedzielna Eucharystia stała się trzecią godziną katechezy w tygodniu? W jaki sposób może pomóc katecheza w spotkaniu z Bogiem w liturgii? Przeżywanie rzeczywistości Kościoła kształtuje się niewątpliwie pod wpływem liturgii. Stąd tak ważne jest odpowiednie jej przygotowanie i wtajemniczenie w jej misterium, które dokonuje się także w ramach katechezy.

Celem artykułu jest więc ukazanie możliwości, jakie stwarza katecheza w prowadzeniu uczniów do składania kultu w liturgii i ofiarowaniu siebie. Chodzi nie tylko o ukazanie elementów kształcenia liturgicznego w ramach katechezy, ale także o taką prezentację liturgii, która stałaby się zaproszeniem do wspólnoty z Jezusem i wejścia z Nim w zażyłą komunię (por. DOK 80). Stąd tematem rozważań o charakterze teologicznym będą nie tylko wzajemne relacje katechezy i liturgii, co przede wszystkim postrzeganie przygotowania do liturgii od strony katechizowanego. Odnowa po Soborze Watykańskim II dotyczyła wszystkich wymiarów życia Kościoła, w tym liturgii i katechezy. Proces odnowy duszpasterstwa zmierza w kierunku katechezy mistagogicznej (por. SmC 64). Jakie są w tym względzie wskazania Podstawy programowej katechezy i Programu nauczania religii? Ukazane w nich cele i zamierzone osiągnięcia są bowiem cenną wskazówką dla katechety w realizacji wskazań Dyrektorium ogólnego o katechizacji i Dyrektorium katechetycznego dla Polski.

\section{KATECHETYCZNY WYMIAR LITURGII}

W okresie katechumenatu istniał silny związek katechezy z liturgią. Katecheza w starożytności chrześcijańskiej w sposób naturalny posiadała charakter wtajemniczający nie tylko dlatego, że pouczanie katechumenów przez

3 Dane statystyczne wskazują na to, że w katechezie w szkole uczestniczy ok. 90\% uczniów, a w niedzielnej Eucharystii od 30 do 40 \% wiernych, co wskazywałoby, że większość uczestników lekcji religii w szkole nie chodzi w niedzielę do Kościoła. 
biskupa i prezbiterów dokonywało się w czasie liturgii, ale ponieważ celem było doprowadzenie do dojrzałej wiary i świadomego przyjęcia sakramentu chrztu. Podział na katechumenów, którzy mogli jedynie uczestniczyć w liturgii słowa (audientes), i na katechizowanych (fideles), a więc już ochrzczonych, gromadził i jednych i drugich na wspólnej katechezie, która miała charakter spotkania o charakterze liturgicznym ${ }^{4}$. W ten sposób wszyscy brali czynny udział w nabożeństwach, odmawiając lub śpiewając psalmy, słuchając słowa Bożego. Wychowawczy wpływ liturgii zwiększał się jeszcze od III wieku, kiedy liturgia zaczęła przybierać coraz bogatsze formy: egzorcyzmy, uroczyste wyznanie wiary, obrzędy chrztu świętego itp. ${ }^{5}$ Katecheza odbywa się zazwyczaj rano, przed pójściem do pracy, w ramach wspólnotowej celebracji liturgii, ponieważ katechumeni należą już w pewnym sensie do Kościoła, choć niecałkowicie. Udział katechumenów w liturgii słowa wraz z wiernymi kończy się modlitwą $\mathrm{z}$ włożeniem rąk, który jest z pewnością gestem egzorcyzmu $\mathrm{u}^{6}$. Sam katechumenat jest więc przykładem ścisłego powiązania katechezy przygotowującej do chrztu z liturgią. Po upadku katechumenatu zaznaczył się stopniowy rozdział, którego przejawem stał się zanik katechizacyjnej liturgii . Dopiero pod koniec XIX wieku w ramach odnowy ruchu liturgicznego nastąpił powrót do tej funkcji liturgii. Katecheza potrzebowała liturgii do uaktywnienia czynu religijnego, którym był czyn liturgiczny, by z kolei w liturgii szukać materiału do wywołania przeżyć religijnych. Stąd liturgia jest wypełnieniem katechezy, ponieważ urzeczywistnia ona dzieło zbawcze, a przez znaki liturgiczne włącza człowieka w rzeczywistość nadprzyrodzoną8.

Ścisły związek katechezy z liturgią doprowadził, zwłaszcza po Soborze Watykańskim II, do wypracowania nie tylko teoretycznych podstaw, ale i praktycznych programów formacyjnych, wśród których na szczególną uwagę zasługuje program formacji liturgicznej ks. Franciszka Blachnickiego w ramach tzw. Oazy Dzieci Bożych 9 . Teologiczną podstawą do rozważań na temat liturgii stanowiły dla Blachnickiego dokumenty II Soboru Watykańskiego, a zwłaszcza Konstytucja dogmatyczna o Kościele "Lumen gentium" oraz Konstytucja o świętej liturgii „Sacrosanctum Concilium”. Widział on ścisłą współzależność pomiędzy istotą Kościoła a istotą liturgii do tego stopnia, że „sposób pojmowania istoty i znaczenia liturgii dla życia Kościoła jest w każdej epoce ściśle zależny od panującej koncepcji Kościoła albo też odwrotnie: sposób pojmowania liturgii

\footnotetext{
${ }^{4}$ Por. R. Murawski, Wczesnochrześcijańska katecheza, Płock 1999, s. 185.

${ }^{5}$ Por. E. Majcher, Historia katechezy, Warszawa 1990, s. 6.

${ }^{6}$ Por. M. Dujarier, Krótka historia katechumenatu, Poznań 1990, s. 44.

${ }^{7}$ Por. J. Szpet, Dydaktyka katechezy, Poznań 1999, s. 75.

${ }^{8}$ Por. tamże, s. 75.

${ }^{9}$ Zob. m.in. M. Sędek, Drogi dojrzatości, Krościenko 2002.
} 
rzutuje na koncepcję Kościoła"10. Wychowanie liturgiczne jest zresztą główną cechą Ruchu Światło-Życie. Dokonuje się ono poprzez stałą formację ściśle związaną z życiem sakramentalnym. W ramach cyklu spotkań formacyjnych na Oazie Rekolekcyjnej, po tematach skoncentrowanych wokół Biblii, program ruchu powraca do formacji liturgicznej. Głównym elementem tej formacji jest przeżywanie roku liturgicznego przez nawiązanie do czytań mszalnych i tekstów liturgicznych z poszczególnych niedziel. Szczególną uwagę zwraca się na przeżycie misterium Triduum Paschalnego przez wzorowo przygotowaną liturgię triduum wraz z liturgią godzin. Szczególnie eksponowane odnowienie przyrzeczeń chrzcielnych odpowiada w katechumenacie czasowi przyjęcia sakramentów inicjacji ${ }^{11}$. Celem więc formacji liturgicznej jest pełniejsze włączenie uczestników w życie Kościoła, w tym przez wdrażanie do parafialnej służby liturgicznej ${ }^{12}$. W ten sposób katecheza systematycznie wprowadza w misterium chrześcijaństwa poprzez wiązanie jej z rokiem liturgicznym.

Po Soborze Watykańskim II pojawiło się w tym względzie szereg nowych określeń: formacja liturgiczna, wychowanie liturgiczne, nauczanie liturgiczne, katecheza liturgiczna. Warto więc w tym miejscu przytoczyć definicję katechezy liturgicznej. Z punktu widzenia dydaktyki katechetycznej rozumie się ją jako „,całościowe wprowadzenie do liturgii, a w konsekwencji oparte na liturgii świętowanie wiary"13. Stopniowy powrót liturgii do katechezy i katechezy do liturgii znalazł potwierdzenie w adhortacji o katechizacji Catechesi tradendae (1979) Jana Pawła II: „Katecheza z natury swej jest związana z całym sprawowaniem liturgii i sakramentów, gdyż właśnie w sakramentach, a zwłaszcza w Eucharystii, Jezus Chrystus najpełniej działa w celu przemiany człowieka" (CT 23). Źródłem takiej postawy jest z pewnością definicja katechezy, którą podaje Jan Paweł II we wspomnianej adhortacji, kiedy stwierdza, że „katecheza jest wychowaniem w wierze dzieci, młodzieży i dorosłych, a obejmuje przede wszystkim nauczanie doktryny chrześcijańskiej, przekazywane na ogół w sposób systematyczny i całościowy, dla wprowadzenia wierzących w pełnię życia chrześcijańskiego" (CT 18). Definicję tę można przedstawić za pomocą następującego schematu:

katecheza to:

wychowanie w wierze $\rightarrow$ formacja

nauczanie wiary $\rightarrow$ informacja

wtajemniczenie $\rightarrow$ liturgia

Takie ujęcie katechezy wskazuje z jednej strony na istotny element formacyjny, a z drugiej na praktykę życia chrześcijańskiego, która wyrazi się w peł-

\footnotetext{
${ }^{10}$ F. Blachnicki, Kościót jako wspólnota, Lublin 1992, s. 139.

${ }^{11}$ Por. Ordo Initiationis Christianae Adultorum, „Notitiae” 8 (1972), s. 27-36.

12 Por. M. Sędek, Drogi dojrzałości, s. 164-165.

${ }^{13}$ J. Szpet, Dydaktyka katechezy, s. 76.
} 
nym uczestnictwie we wspólnocie kościelnej przez sprawowanie sakramentów oraz świadectwo życia apostolskiego i misyjnego (por. CT 18). Jeszcze pełniej cel katechezy został określony w Dyrektorium ogólnym o katechizacji (1997), w którym chodzi już nie tylko o spotkanie z Chrystusem, ale o doprowadzenie do zjednoczenia, a nawet głębokiej z Nim zażyłości (por. DOK 80). Komunia z Jezusem nie jest możliwa bez kultu, którego najdoskonalszą formą jest Eucharystia. Dlatego katecheza ma pomóc temu, kto się nawrócił, poznać „tajemnicę” Boga i pójść za Chrystusem. W ten sposób katecheza zakłada już u katechizowanego pierwotną wiarę, która wymaga jeszcze umocnienia, ale pozwala już pełniej uczestniczyć w liturgii. Takie założenie jest konieczne, ponieważ, jak stwierdził papież Jan Paweł II, „życie sakramentalne ubożeje i bardzo szybko zostaje sprowadzone do zewnętrznego rytualizmu, jeśli nie jest oparte na pogłębionej znajomości znaczenia sakramentów, a sama katecheza, jeśli nie jest ożywiana życiem sakramentalnym, przybiera formę czystego intelektualizowania" (CT 23). Najpierw więc jest konieczne wychowanie do decyzji wiary, czyli pragnienia pójścia za Chrystusem, co dokonuje się przez działanie ewangelizacyjne, potem następuje wychowanie w wierze realizujące się przez systematyczną katechezę, a w końcu wychowanie do życia z wiary dla chrześcijanina dojrzałego, który realizuje swoje życiowe powołanie przez apostolstwo i dawanie świadectwa Chrystusowi. Owocność i zarazem skuteczność procesu wychowania w wierze zależy bez wątpienia od w pełni świadomego i czynnego udziału w liturgii.

Z kolei papież Benedykt XVI w adhortacji apostolskiej Sacramentum caritatis, zwracając uwagę na wychowawczą rolę liturgii, stwierdza, że: „liturgia ma z samej swej istoty pedagogiczną zdolność wprowadzania wiernych w pojmowanie celebrowanej tajemnicy" (SmC 64). W ten sposób Papież zwraca uwagę na formowanie chrześcijan przez doświadczenie, które od początku w Kościele dokonywało się przez dzielenie się wiarą autentycznych świadków Chrystusa (por. Rz 1,11). Katechizm Kościoła Katolickiego zwraca uwagę na katechezę liturgiczną, która ma na celu wprowadzenie w misterium Chrystusa (jest „mistagogią"), przechodząc od tego, co widzialne, do tego, co niewidzialne, od znaku do tego, co on oznacza, od „sakramentów” do misteriów (KKK 1075). Liturgia jest więc "uprzywilejowanym miejscem dla katechezy Ludu Bożego" (KKK 1074). Odnowa katechezy zmierza do uznania w Jezusie Chrystusie jedynego Pana i Zbawiciela świata i człowieka przez wtajemniczenie, które dokonuje się w oddawaniu czci Bogu w czasie sprawowania liturgii. W ten sposób liturgia nadaje sens i kierunek katechezie nie tylko w odniesieniu do treści, ale także w poszukiwaniu adekwatnych metod katechetycznych, które przyczyniłyby się do przyjęcia wiary chrześcijańskiej jako drogi prowadzącej do wspólnoty z Bogiem i z ludźmi.

Wśród podstawowych zadań katechezy znajduje się przygotowanie do życia modlitwy i życia liturgiczno-sakramentalnego oraz budzenie i pielęgno- 
wanie wspólnoty oraz wychowywanie do chrześcijańskiego i moralnego życia ${ }^{14}$. Cenną w tym względzie uwagę znajdujemy w odniesieniu do przygotowania dzieci do I Komunii Świętej, które nie może się ograniczać jedynie do przyswajania wiadomości o Eucharystii, ale cała uwaga powinna być skupiona na powiązanej ściśle z liturgią katechezie ewangelizacyjnej, która „zarówno dziecku, jak i bliskiemu mu środowisku, pozwala przeżyć wydarzenie pierwszokomunijne jako katechumenalny proces ożywiania związku z Chrystusem i Kościołem”15. Takie ujęcie katechezy wyraźnie nawiązuje do starożytnej katechezy, która miała charakter ewangelizacyjny i katechumenalny.

Ponadto Dyrektorium katechetyczne Kościoła katolickiego w Polsce stwierdza, że to katecheza powinna budzić postawy i kształtować umiejętności prowadzące do owocnego udziału w życiu sakramentalnym dziecka (por. PDK 25), co wskazuje na ścisłą zależność jakości przeżywanej liturgii od katechezy sakramentalnej. Już zresztą sługa Boży papież Jan Paweł II w adhortacji o katechizacji wskazał, że „nie może istnieć autentyczna praktyka sakramentalna, która by nie miała jakiegoś charakteru katechetycznego" (CT 23). Katecheza ma więc prowadzić zarazem do dojrzałej wiary i do zjednoczenia z Bogiem. Jednym ze środków umożliwiających to zjednoczenie jest modlitwa, która przemienia sposób myślenia i działania. W ten sposób katecheza przeniknięta klimatem modlitwy pozwala prowadzić życie chrześcijańskie w komunii z Jezusem i odkrywać działanie Boga w ich życiu (por. DOK 85). Dlatego nie tylko katecheci, ale także rodzice powinni już od najmłodszych lat uczyć dzieci modlitwy prywatnej. Jeśli tak przygotowane dzieci biorą udział we Mszy świętej, to „łatwiej zaczną śpiewać i modlić się we wspólnocie liturgicznej, a nawet będą już jakoś wyczuwać eucharystyczną tajemnicę" (DMD 10).

Problemy liturgii są jedną z tych spraw, które papież Benedykt XVI chce uporządkować w czasie swego pontyfikatu. Już we wspomnianej adhortacji apostolskiej Sacramentum caritatis zwraca on uwagę na wychowanie w wierze eucharystycznej, która uzdalnia wiernych do osobistego przeżywania tego, co się celebruje. Dlatego najlepszą katechezą o Eucharystii jest sama Eucharystia dobrze celebrowana (por. SmC 64). Z tego tytułu rodzi się postulat katechezy mistagogicznej, która, według Papieża, powinna zawsze uwzględniać trzy elementy: objaśnienie obrzędów w świetle wydarzeń zbawczych, zgodnie z żywą tradycją Kościoła, wprowadzenie wiernych w znaczenie znaków zawartych w obrzędach i ukazanie wiernym znaczenia obrzędów w powiązaniu z życiem chrześcijańskim we wszystkich jego wymiarach (por. SmC 64). Wymienione zadania katechezy mistagogicznej stanowią pilne wyzwanie w naszych czasach,

${ }^{14}$ Por. F. Blachnicki, Katechetyka Fundamentalna, Warszawa 2006, s. 147.

${ }^{15}$ S. Hartlieb, Pierwsza Komunia święta. Droga wtajemniczenia w Paschę Chrystusa, Kraków 1996, s. 9. 
ponieważ wielu ludzi o myśleniu technicznym zatraciło dziś zdolność rozumienia znaków i symboli. Dlatego nie wystarczy dziś jedynie sama informacja, ale też wychowanie do poprawnego odczytywania znaków oraz nabywanie umiejętności symbolizowania. W ten sposób sama liturgia odpowiednio przygotowana i starannie celebrowana stanie się dla współczesnego chrześcijanina nie tylko istotnym elementem kształcenia liturgicznego, ale drogą do komunii z Jezusem. Taki postulat wymaga od odpowiedzialnych za liturgię autentycznego świadectwa, w przeciwnym razie grozi zejście do poziomu zewnętrznego rytualizmu.

Warto jeszcze zwrócić uwagę na uwagi papieża Benedykta XVI w motu proprio Summarum pontyficum, który znosząc ograniczenia w odprawianiu mszy trydenckiej, pokazuje, że liturgia nawiązuje do tradycji obrzędów i modlitw średniowiecznych, a nawet wczesnochrześcijańskich. W ten sposób Papież pragnął zwrócić uwagę, z jednej strony na bogactwo form liturgicznych w historii Kościoła, a z drugiej chciał uporządkować w duchu reformy dowolność liturgiczną, która może prowadzić do błędów doktrynalnych. Zwrócenie uwagi współczesnemu chrześcijaninowi na bogatą tradycję liturgiczną stanowi niewątpliwie wyjście naprzeciw potrzebie poszukiwania form i sposobów oddawania Bogu czci w liturgii. Przywiązanie do starych rytów liturgicznych w języku łacińskim, pielęgnowane przez niektórych chrześcijan, nie musi oznaczać tradycjonalizmu, ale w wielu przypadkach jest pragnieniem „uratowania” tego dziedzictwa, które było dla przodków drogą do świętości. Dlatego odnowa liturgiczna w procesie katechezy zmierza $\mathrm{w}$ kierunku mistagogicznym, tzn. $\mathrm{z}$ jednej strony chodzi o większe przeżycie sacrum, które sprawia, że wierni dzisiaj wszystko słyszą, widzą i więcej niż kiedyś rozumieją. Właśnie możliwość rozumienia treści odmawianych modlitw mobilizuje do pogłębionej katechezy liturgicznej. Dlatego dokument Benedykta XVI uświadamia potrzebę edukacji liturgicznej nie tylko kapłanów, ale także i wiernych.

\section{LITURGICZNY WYMIAR KATECHEZY}

Kościół żyje Eucharystią (por. EdE 1), dlatego wszyscy jego członkowie są wezwani do życia głębią tego sakramentu. W nim bowiem jednoczą się z Dawcą życia, który czyni ich uczestnikami zbawczych wydarzeń. W oczekiwaniu na powtórne przyjście Chrystusa Kościół przygotowuje swych wiernych do tego wydarzenia przez głoszenie Słowa, liturgię i katechezę ${ }^{16}$. Dlatego papież Jan Paweł II w adhortacji o katechizacji wprost stwierdza, że „katecheza z natury swej jest związana $\mathrm{z}$ całym sprawowaniem liturgii i sakramentów, gdyż właśnie w sakramentach, a zwłaszcza w Eucharystii, Jezus Chrystusa najpełniej

${ }^{16}$ Por. S. Suwiński, Wychowanie dziecka do życia Eucharystiq, „Ateneum Kapłańskie” 147 (2006), s. 61. 
działa w celu przemiany człowieka" (CT 23). Należy zwrócić uwagę na fakt, że wszystkie dokumenty katechetyczne po Soborze Watykańskim II podkreślają silny związek katechezy z liturgią. Katecheza bowiem czerpie treści z liturgii i do niej prowadzi, ponieważ jest najważniejszym źródłem wiary po Piśmie Świętym ${ }^{17}$. Nie może jednak na tym poprzestać, ale powinna czerpać z liturgii siłę duchową, aby prawdy wiary i zasady życia chrześcijańskiego, jakie poznają uczniowie w czasie katechezy, mogły być skutecznie realizowane w ich życiu ${ }^{18}$. Dlatego katechizowani mogą stawać się świadkami Boga w świecie, dzięki mocy Chrystusa działającego w liturgii, która „w najwyższym stopniu przyczynia się do tego, aby wierni życiem swoim wyrażali oraz ujawniali innym misterium Chrystusa i rzeczywistą naturę Kościoła” (KL 2). Kościół pragnie, aby „wszyscy wierni zostali doprowadzeni do pełnego, świadomego i czynnego uczestnictwa w sprawowaniu Liturgii" (KL 14). Chrześcijanin bowiem w najbardziej oczywisty sposób wyznaje wiarę wtedy, gdy „czynnie uczestniczy w liturgii, przyjmując sakramenty święte, a w szczególności bierze udział w zgromadzeniu eucharystycznym. Ten czynny i świadomy udział w liturgii może nastąpić tylko w wyniku solidnego wychowania w ramach katechizacji"19.

Człowiek jako istota cielesno-duchowa, uczestnicząc w liturgii, powinien nie tylko być obecny fizycznie, ale poprzez sakramentalne znaki i słowa wejść w relację z żywym i osobowym Bogiem. Dlatego konieczne jest wyjaśnienie znaków i symboli obecnych w liturgii, ponieważ to, co dokonuje się w czasie liturgii mszalnej w sposób niewidoczny, doświadczane jest i wypowiadane przez znaki ${ }^{20}$. Do tego odnosi się Katechizm Kościoła Katolickiego, kiedy stwierdza, że „znaki i symbole zajmują ważne miejsce w życiu ludzkim. Człowiek, jako istota cielesna i duchowa, wyraża i rozumie rzeczywistości duchowe za pośrednictwem znaków i symboli, by komunikować się z innymi za pośrednictwem języka, gestów i czynności. To samo odnosi się do relacji z Bogiem" (KKK 1148). Aby doświadczyć obecności Boga poprzez znaki liturgiczne, trzeba posiąść umiejętność odkrywania Jego obecności za pomocą znaków zwyczajnych. Wprowadzenie w symbolikę liturgiczną winno więc być poprzedzone wychowaniem do umiejętności patrzenia na to, co dokonuje się w świecie jako znaki, które mówią o Bogu ${ }^{21}$. Nie należy jednak zapominać o tym, że przeżycie jest ważniejsze od wyjaśnień, ponieważ sam przekaz treści wzbo-

${ }^{17}$ Por. J. Szpet, Dydaktyka katechezy, s. 75.

${ }^{18}$ Por. Cz. Krakowiak, Formacja katechizowanych do świadomego i czynnego udziatu we Mszy świętej, „Roczniki Teologiczne” 6 (2006), s. 307-308.

${ }^{19}$ T. Chromik, T. Kubik, Liturgia a katecheza, „Ruch Biblijny i Liturgiczny” 20 (1967), s. 160 .

${ }^{20}$ Por. G. Hansemann, Wychowanie religijne, Warszawa 1988, s. 220-221.

${ }^{21}$ Por. J. Grześkowiak, Katecheza a wychowanie do symboliki liturgicznej, „Katecheta” 20 (1976), s. 198. 
gaca jedynie wiedzę, ale nie uzdalnia jeszcze w pełni do sprawowania kultu. Formacja ma więc zmierzać do tego, aby dziecko nauczyło się dostrzegać teologiczny wymiar otaczającej go rzeczywistości. Ma wprowadzić w religijną „naturalną medytację”, która stanowi fundament obrzędu liturgicznego. Chodzi o nabycie takich umiejętności, które umożliwiają przeżywanie wszelkich wydarzeń z pełnym zaangażowaniem całej osobowości oraz władz fizycznych i duchowych w takie akty, jak słuchanie, oglądanie, działanie ${ }^{22}$. Z uwagi na to, że zatraciła się w wielu przypadkach zdolność do rozumienia znaków i symboli, „katecheza powinna wzbudzić i wychować wrażliwość wiernych na język znaków i gestów, które w połączeniu ze słowem stanowią obrzęd" (SmC 64). Wyjaśniania symboli nie można sprowadzać tylko do zrozumienia ich treści, ale winny być one przedstawione we właściwym otoczeniu, które będzie sprzyjać ich przeżywaniu ${ }^{23}$. Zrozumienie przez katechizowanego znaku liturgicznego wymaga bowiem najpierw poznania jego istoty. Podstawowym zaś znakiem w liturgii jest Jezus Chrystus, ponieważ w Jego człowieczeństwie ukrywa się i zarazem objawia człowiekowi niewidzialny Bóg, który jest podstawą obecności widzialnych znaków w liturgii. W ten sposób aktywne i owocne uczestnictwo katechizowanych w sprawowanym kulcie zależy w dużej mierze od umiejętności rozpoznania wielkiej tajemnicy wiary, jaką jest obecność Boga w liturgii. Przed katechezą stoi więc ogromne i odpowiedzialne zadanie, które zostało wyraźnie określone w najnowszych dokumentach katechetycznych.

Zarówno Podstawa programowa katechezy, jak i Program nauczania religii integrują treści liturgiczne z katechezą, zgodnie z podstawowymi celami katechezy, wśród których wychowanie liturgiczne stanowi jedno z ważniejszych zadań. Komunia z Jezusem w sposób naturalny prowadzi do celebracji Jego zbawczej obecności w sakramentach, a szczególnie w Eucharystii (por. DOK 85). Dlatego zadaniem katechezy będzie odpowiednie przygotowanie wiernych do pełnego, świadomego i czynnego udziału w liturgii (por. KL 14). Już Directorium Catechisticum Generale z 1971 roku postulowało bowiem, aby katecheza oprócz ukazywania znaczenia liturgii i sakramentów, „nie ograniczając się wyłącznie do wyjaśniania znaczenia obrzędów, wychowywała wiernych wewnętrznie do modlitwy, dziękczynienia, czynienia pokuty, odmawiania modlitw z ufnością, do ducha wspólnoty, właściwego zrozumienia symboliki" (DCG 25). Z tego tytułu można już mówić o katechezie liturgicznej, która prowadzi do liturgii, formując katechizowanych we wspólnocie Kościoła. Stąd treść katechezy zawarta w słowie Bożym jest przedmiotem czci w liturgii (por. DCG 45).

\footnotetext{
22 Por. tamże, s. 202.

${ }^{23}$ Por. A. Hajduk, Wychowanie do rozumienia znaków i symboli liturgicznych, „Horyzonty Wiary" 9 (1998), s. 5.
} 
Obecność wychowania liturgicznego w katechezie jest dziś czymś naturalnym, tak jak czymś naturalnym i oczywistym jest przeżywanie roku liturgicznego w Kościele. Na wszystkich etapach edukacyjnych Podstawa programowa katechezy postuluje wiele treści i celebracji liturgicznych ${ }^{24}$. Warto w tym miejscu dokonać także spojrzenia na formację liturgiczną w katechezie w świetle Programu nauczania religii, jednak bez szczegółowego omawiania zagadnień związanych z liturgią w poszczególnych klasach, ponieważ wykraczałoby to poza ramy tego artykułu. Chodziłoby o to, aby wydobyć z Programu kierunki formacji liturgicznej w katechezie dzieci i młodzieży. Już bowiem w nauczaniu przedszkolnym dzieci powinny odkrywać bliskość Boga w katechezie i liturgii, podejmując $z$ Nim dialog przez modlitwę ${ }^{25}$. Wprowadzenie $w$ rozumienie podstawowych znaków i czynności liturgicznych oraz wprowadzenie do uczestnictwa w liturgii stanowi dla przedszkolaka pierwsze, w miarę świadome zetknięcie się z akcją liturgiczną 26 . Oczywiście trudno wymagać w tym wieku dojrzałych postaw, ale dziecko, idąc z dorosłymi do Kościoła, powoli będzie „wchodzić” w relację z Bogiem, choć jeszcze nie będzie mogło Go przyjąć w Komunii św. Z kolei założenia nauczania religii dla klas I-III szkoły podstawowej zmierzają do inicjowania wychowania religijno-moralnego uczniów w duchu sakramentu chrztu, pokuty i Eucharystii. Jest czas przygotowania do przyjęcia I Komunii Świętej, stąd treści programowe skoncentrowane będą wokół sakramentów, zwłaszcza Eucharystii oraz roku liturgicznego ${ }^{27}$. Przywoływanie poszczególnych wydarzeń roku liturgicznego ma bowiem na celu nie tylko wspominanie wydarzeń zbawczych, ale ich uobecnienie, wskazując na ich ciągłość realizowania się tu i teraz w Kościele ${ }^{28}$. Na tym więc etapie edukacyjnym można już mówić o inicjacji sakramentalnej.

Program nauczania religii dla klas IV-VI szkoły podstawowej wzywa do życia w jedności z Bogiem we współczesnym świecie. Drogą do realizacji tych zamierzeń jest wprowadzenie uczniów w historię zbawienia, która ukazuje działania Boga na rzecz człowieka zapoczątkowane zawarciem przymierza ${ }^{29}$. Treści katechetyczne w poszczególnych klasach ukazują zbawcze działanie Boga Ojca, Syna i Ducha Świętego, które domaga się szacunku i wdzięczności wobec Boga oraz odpowiedzi na Jego wezwanie. Zgodnie ze wskazaniami

${ }^{24}$ Zob. artykuł na temat wychowania liturgicznego na poszczególnych etapach edukacyjnych w świetle Podstawy programowej katechezy: J. Szretter, Wychowanie liturgiczne, „Katecheza, rodzina, parafia i szkoła” 1 (2003), s. 35-42.

${ }^{25}$ Por. Podstawa programowa katechezy, Kraków 2001, s. 16.

${ }^{26}$ Zob. J. Stala, Katecheza dziecka wieku przedszkolnego, w: Katechetyka szczegótowa, red.

J. Stala, Tarnów 2003, s. 52-53.

${ }^{27}$ Por. Program, s. 11-12.

${ }^{28}$ Zob. J. Stefański, Liturgia dla każdego, Gniezno 1995, s. 61-106.

${ }^{29}$ Por. Program, s. 41. 
do realizacji programu, układ bloków tematycznych powinien być włączony w rok liturgiczny i charakterystyczne dla poszczególnych okresów postawy, co skłania do podjęcia funkcji wtajemniczenia i wprowadzenia w życie modlitwy w ramach liturgii Kościoła ${ }^{30}$.

Nauczanie religii w gimnazjum koncentruje się wokół Kościoła, który jest wspólnotą ludu Bożego. Program zmierza do przygotowania do sakramentu bierzmowania i przyjęcia go we wspólnocie Kościoła. Chodzi nie tylko o przekaz wiedzy religijnej, ale o „wprowadzenie katechizowanych w wyznawanie wiary i praktykę życia chrześcijańskiego"31. Osiągnięcie tego zadania jest możliwe przez powiązanie nauczania religii w szkole z katechezą parafialną. Jednym z istotnych celów katechetycznych na tym etapie edukacyjnym jest uświadamianie religijnego znaczenia okresów i świąt roku liturgicznego oraz uczenie ich przeżywania jako zbawczych wydarzeńn ${ }^{32}$.

W końcu, katecheza młodzieży w szkołach ponadgimnazjalnych dotyczy świadectwa wiary składanego w Kościele, w świecie i w rodzinie. Znów powraca przeżywanie roku liturgicznego, ale w kontekście świadectwa chrześcijańskiego. Chodzi o wprowadzenie w pogłębione życie liturgiczne rozumiane jako źródło i szczyt życia eklezjalnego, którego skutkiem będzie zaangażowanie apostolskie w życie Kościoła lokalnego, a szczególnie parafii ${ }^{33}$. Osiągnięcie zamierzonych celów wymaga od katechety stosowania różnych metod katechetycznych, w tym liturgicznych i biblijnych. W dydaktyce katechetycznej wypracowano wiele metod liturgicznych, które w zależności od poziomu katechizowanych i ich stopnia identyfikacji z Kościołem należy wykorzystywać w katechezie. Wśród metod liturgicznych można wymienić następujące: adoracja, celebracja, medytacja ikony, msza szkolna, nabożeństwa, pielgrzymka, uroczyste czytanie Pisma Świętego ${ }^{34}$.

\section{INKULTURACJA LITURGICZNA W KATECHEZIE}

Rok Eucharystii ogłoszony 7 października 2004 roku przez papieża Jana Pawła II po raz kolejny zwrócił uwagę na fons et culmen życia chrześcijańskiego. Nie chodziło tylko o przypomnienie wartości i znaczenia Eucharystii w życiu Kościoła, ale swoistą inkulturację eucharystyczną, która jako program solidarności dla całej ludzkości stanie się świadectwem dzielenia się z najuboższymi ${ }^{35}$.

${ }^{30}$ Por. tamże, s. 51-52.

${ }^{31}$ Tamże, s. 75-76.

${ }^{32}$ Por. tamże, s. 93.

${ }^{33}$ Por. tamże, s. 105, 115-116.

${ }^{34}$ Por. A. Długosz, Jak przygotowywać i oceniać katechezę, Częstochowa 1997, s. 124-125. Zob także S. Kulpaczyński (red.), Celebracje w katechezie, Lublin 1999.

${ }^{35}$ Por. M. Kowalczyk, Inkulturacja eucharystyczna, „Studia Gnesnensia” XIX (2005), s. 113 . 
Nie bez znaczenia w tym względzie będzie miało samo przygotowanie do Eucharystii w ramach katechezy, która celebrowana we wspólnocie Kościoła stanie się istotnym elementem odnowy duszpasterskiej.

Ważną częścią inkulturacji liturgicznej jest modlitwa liturgiczna. Papież Benedykt XVI w encyklice o nadziei chrześcijańskiej Spe salvi zwraca uwagę na publiczną modlitwę Kościoła, w „której Pan nieustannie uczy nas, jak modlić się właściwie" (SS 34). Stąd znajomość i odmawianie znanych modlitw jak: Ojcze nasz, Zdrowaś Maryjo i modlitw liturgicznych pozwala przetrwać trudne chwile, w których człowiek „nie potrafi” się modlić. W ten sposób liturgia staje się miejscem uczenia się i ćwiczenia nadziei. Charakterystyczną cechą modlitwy Kościoła jest dziękczynienie celebrowane w Eucharystii. Każda msza święta jest ze swej natury dziękczynieniem, dlatego ta właśnie modlitwa Kościoła pozwala uczestniczyć członkom Mistycznego Ciała w dziękczynieniu Głowy (por. KKK 2637). Mówiąc o liturgii Kościoła, trzeba mieć na względzie fakt, że uobecniane misterium zbawienia znajduje swoje przedłużenie $\mathrm{w}$ modlącym się sercu. „Modlitwa bowiem uwewnętrznia i przyswaja liturgię podczas i po jej celebracji. Nawet jeśli modlitwa jest przeżywana «w ukryciu» (Mt 6, 6), jest zawsze modlitwą Kościoła i komunią z Trójcą Świętą" (KKK 2655). Takie rozumienie modlitwy Kościoła wskazuje na potrzebę systematycznego wdrażania do modlitwy Kościoła w ramach katechezy. Nie chodzi bynajmniej o ćwiczenie różnych celebracji liturgicznych, ale o formację liturgiczną, która nie może ograniczać się jedynie do przekazywania informacji na temat znaczenia gestów i symboli używanych w liturgii czy nawet wyjaśnienia poszczególnych części mszy świętej. Istotnym elementem jest prowadzenie uczniów do świadomego, pełnego i owocnego przeżywania każdej liturgii, która stanowi życie Kościoła. Katecheza, która nie prowadzi do Kościoła, prowadzi bowiem do niewiary. Bez czynnego włączenia się w modlitwę Kościoła katechizowany znajdzie się jakby „na uboczu”, a czasem może także stracić wiarę. Dzięki modlitwie będzie on mógł razem z innymi odnaleźć swoje miejsce i zadanie we wspólnocie Kościoła. Dydaktyka modlitwy w ramach katechezy ściśle wiąże się z wychowaniem liturgicznym, ponieważ jednoczenie się z Bogiem, nawet prywatne, stanowi zawsze element liturgii Kościoła.

W ramach inkulturacji liturgicznej mieści się także inkulturacja sakramentalna. Adaptacja chrześcijaństwa na przestrzeni dziejów objęła swym zasięgiem nie tylko przestrzeń geograficzną, ale także psychosocjologiczną. Dlatego Ewangelia mogła przemienić sposób myślenia, działania, a nawet tradycje i zwyczaje $\mathrm{e}^{36}$. Interesujące $\mathrm{w}$ tym względzie są określenia sakramentów w Katechizmie Kościoła Katolickiego, wynikające z tego, że w Kościele powszechnym istnieje duża różnorodność obrządków powstałych w historii Kościoła. Dlatego

\footnotetext{
${ }^{36}$ Por. M. Kowalczyk, Inkulturacja, s. 46.
} 
należało znaleźć takie określenia, które byłyby możliwe do zaakceptowania przez różne tradycje liturgiczne. Nie było to proste zadanie przy redagowaniu Katechizmu, niemniej jednak udało się znaleźć w ramach inkulturacji następujące określenia sakramentów wyrażające zbawczą tajemnicę: sakramenty Chrystusa, sakramenty Kościoła, sakramenty wiary, sakramenty zbawienia i sakramenty życia wiecznego ${ }^{37}$. Powyższe nazwy wskazują na istotę działania Boga w sakramentach, dlatego ich wyjaśnienie jest zadaniem katechezy, która w ramach przygotowania do świadomego przyjęcia sakramentów powinna posługiwać się pojęciami wypracowanymi przez Katechizm. W ten sposób inkulturacja zmierza do wzbogacania Kościoła powszechnego nowymi środkami wyrazu Kościołów lokalnych.

\section{CATÉCHÈSE ET LITURGIE: AU SENS DE RENOUVEAU RÉSUMÉ}

La liturgie n'est pas de la catéchèse et la catéchèse n'est pas de la liturgie. Mais cela traduit surtout une attitude de séparation des domaines respectifs, bien antérieure à toute confusion possible. La liturgie ou la catéchèse restent dans leurs casiers qui ne font que glisser l'un à côtè de l'autre. Des programmes catéchétiques sont aujourd'hui proches de souci liturgique. Cela nous pose des questions de ne pas séparer ce qui a vocation commune, c'est-a-dire présenter et prier le mystčre chrétien. Ce pourquoi notre reflection théologique montre la nécessité de la liturgie dans la pratique catéchétique. C'est donc pour des raisons théologiques et pastorals qu'on propose la catéchèse liturgique dans toutes les étapes édoucatives. Les catéchèses, comme aux débuts de l'Eglise, doivent redevenir aujourd'hui un chemin qui introduise dans la vie liturgique (catéchèse mystagogique). Enfin, dans une optique prospective il faut prendre en compte aussi les exigences concrètes de l'inculturation liturgique dans la catéchèse. Il s'agit de l'économie sacramentelle, le cycle liturgique, les hymnes et texts liturgiques, les priers.

\footnotetext{
${ }^{37}$ Por. M. Napieralski, O nowym katechizmie, Poznań 1994, s. 64-65.
} 